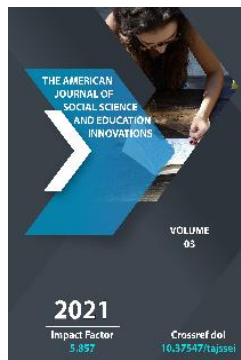

\title{
The Problem Of Periodization And The Views Of Civilization In The History Of Uzbekistan
}

\author{
Anvar Bakiev \\ Researcher, Termez State University, Uzbekistan
}

Journal Website:

http://usajournalshub.c om/index,php/tajssei

Copyright: Original content from this work may be used under the terms of the creative commons attributes 4.0 licence.

\section{ABSTRACT}

The article is devoted to problem the history of Uzbekistan`s timing. In the present case, the history of failure is about the achievement and defect of archeological, chronological, dynastic, formational ethnographic and civilizational approaches.

\section{KEYWORDS}

Periodization, archaeology, dynasty, formation, civilization, Plenum, urbanization, pictographic signs, Renaissance.

\section{INTRODUCTION}

There are various methods of periodization of human history, which are archeological, chronological, dynastic, ethnographic, formational, and, of course, civilizational approaches. There are also specific shortcomings of these methods in the periodization of history. The history of the peoples of Central Asia was first periodized by 
the academician V.V. Bartold [1: 3 p]. These views of V.V. Barthold were based on available written sources, and subsequent studies have shown that this periodization is not acceptable [2:15-24 P]. In this regard, V.V. Struve, based on the sources of the Ancient East, "justified the existence of slavery" in Central Asia even before the Muslim period [3: 23-34 b].

\section{THE MAIN RESULTS AND FINDINGS}

In the periodization of the ancient history of the peoples of Central Asia, it is also worth mentioning the services of S.P. Tolstov. He also acknowledges that in pre-Muslim times there was "slavery" in the country [4: 3-21 p]. The issue of periodization was discussed in detail at the plenum in Leningrad in 1948 [5: 8-28 p] and at the session in Tashkent in 1954 [6]. It has become a tradition in the history of the Soviet period to study the history of human society in five socio-economic formations [7:15 p]. The history of Uzbekistan has also been periodized mainly on the basis of a formational approach. It is known that the authors of the idea themselves noted that the method developed by the creators of periodization on the basis of a five-stage formation of history was written for the history of European peoples, not suitable for the history of Asian peoples [8]. As a result of uneven development, the lack of capitalism in Asia led to the emergence of the "Asian method of production" for Marxists and the theory of "jumping around capitalism" for Leninists [8: 26-36 p]. Hence, the inadequacy of the formational periodization of history for the history of the peoples of Asia, including Central Asia, has been known since the birth of the idea.

Periodization of the history of Uzbekistan on the basis of dynasties can also be the basis for a brighter study of our history[9]. If we pay attention to the chronology of the history of Uzbekistan, the system of public administration, we can trace the dynasties and the process of their exchange in very long periods. However, this approach may not be methodologically correct when studying the history of the Achaemenid period or the new and most recent periods, in the sense that the method of dynastic periodization does not cover all chronological periods of history.

In our opinion, one of the most acceptable options for periodizing history is a civilizational approach to it. Much has been done in the history of the world in the direction of civilization, that is, urbanization. Well-known archaeologist and urbanist K.Renfrew gave a scientific definition of civilization, arguing that society is a stage of cultural development in which society should be class-stratified and statehood formed [10: $213 \mathrm{p}]$.

In the 50 s of the last century, G.Chaild revealed the features of the Ancient Eastern and European civilizations [11; 12; 13: 9-16 p]. 
The existence of the first signs of civilization in Sopolli culture, according to G. Chaild

\begin{tabular}{|c|c|c|c|}
\hline $\begin{array}{c}\text { The first signs of } \\
\text { civilization according to } \\
\text { the views of the scientist } \\
\text { until } 1958\end{array}$ & $\begin{array}{l}\text { Observations of the first signs of } \\
\text { civilization at the Djarkutan } \\
\text { monument }\end{array}$ & $\begin{array}{l}\text { According to } \\
\text { his views after } \\
1958\end{array}$ & $\begin{array}{l}\text { Observations of the } \\
\text { first signs of } \\
\text { civilization at the } \\
\text { Djarkutan } \\
\text { monument }\end{array}$ \\
\hline Formation of states & $\begin{array}{c}\text { Existence of palace and temple, } \\
\text { administration }\end{array}$ & \multirow{3}{*}{ The first cities } & \multirow{3}{*}{ Djarkutan city-state } \\
\hline Class relations & $\begin{array}{c}\text { Presence of monumental and } \\
\text { simple architectural buildings, rich } \\
\text { and poor tombs }\end{array}$ & & \\
\hline $\begin{array}{l}\text { The emergence of the } \\
\text { first cities }\end{array}$ & $\begin{array}{l}\text { Becoming a center of advanced } \\
\text { handicrafts, trade, ideology }\end{array}$ & & \\
\hline Tax system & $?$ & \multirow{4}{*}{ Writing } & \multirow{4}{*}{$\begin{array}{l}\text { Pictographic signs, } \\
\text { material writing } \\
\text { system }\end{array}$} \\
\hline Advanced sales & $\begin{array}{c}\text { Finding samples of material culture } \\
\text { typical of Harappa, Elam, Syria, } \\
\text { Hittite, Andronova cultures in } \\
\text { Jarqotan }\end{array}$ & & \\
\hline Advanced craftsmanship & $\begin{array}{c}\text { Architecture, ceramics, metallurgy, } \\
\text { jewelry }\end{array}$ & & \\
\hline Writing & Pictographic signs, material writing & & \\
\hline $\begin{array}{l}\text { A form of land ownership } \\
\text { passed down from } \\
\text { generation to generation }\end{array}$ & Artificial irrigation-based farming & \multirow{3}{*}{$\begin{array}{l}\text { Monumental } \\
\text { architecture }\end{array}$} & \multirow{3}{*}{$\begin{array}{c}\text { Djarkutan fire } \\
\text { temple, palace, } \\
\text { defense structures }\end{array}$} \\
\hline Monumental building & Temple, palace, defense structures & & \\
\hline $\begin{array}{c}\text { Formation of science and } \\
\text { art symbols }\end{array}$ & $\begin{array}{c}\text { Geometric units, symmetry, maze, } \\
\text { sculpture }\end{array}$ & & \\
\hline
\end{tabular}

According to the Chicago Conference (1958), the existence of the first signs of civilization in the Sopolli culture

\begin{tabular}{|c|c|c|}
\hline № & $\begin{array}{c}\text { Signs of the first civilization adopted at the } \\
\text { Chicago Conference }\end{array}$ & $\begin{array}{c}\text { Representation of the signs of the first civilization } \\
\text { in Djarkutan }\end{array}$ \\
\hline 1. & Formation of states & Djarkutan city-state \\
\hline 2. & The formation of the writing & Pictographic symbols and material writing system \\
\hline 3. & Separation of agriculture from handicrafts & Formation of artisan quarters in Jarqotan \\
\hline $4 \cdot$ & Formation of class society & $\begin{array}{c}\text { Presence of monumental and simple architectural } \\
\text { buildings, rich and poor tombs }\end{array}$ \\
\hline
\end{tabular}


The American Journal of Social Science and Education Innovations

(ISSN - 2689-100x)

Published: April 28, 2021 | Pages: 158-171

Doi : https://doi.org/10.37547/tajssei/Volumeo3Issue04-24

2021: 5.857

OCLC - 1121105668

\begin{tabular}{|l|l}
\hline 5. & The emergence of cities
\end{tabular}

The transformation of Jarqotan into a developed center of handicrafts, trade, and ideology

Some urbanist scholars, including R. Mc Adams

[14: 345-357 b], V.Feyrservis [15: 68-73 b], K.Flanner [16: 21-34 b], described the features of ancient Eastern civilization, the cultural development of human history - studied its role in the development of other civilizations.

It should be acknowledged that the British scientist A. Toynbee made a significant contribution to the study of the process of formation and improvement of civilizational views in the development of society'. He argues that humanity has experienced 26 civilizations on earth [17; 18]. Below are Arnold Toynbee's civilized views on human development.

\begin{tabular}{|c|c|c|}
\hline № & $\begin{array}{l}\text { Civilizational stages of society } \\
\text { development }\end{array}$ & Civilizations \\
\hline I. & Primitive society & \\
\hline \multirow{5}{*}{ II. } & \multirow{5}{*}{$\begin{array}{l}\text { Early civilizations } \\
\text { (Primitive Civilization) }\end{array}$} & Egypt \\
\hline & & Sumer \\
\hline & & Harappa \\
\hline & & Minoy \\
\hline & & Ancient China (Shan) and others \\
\hline \multirow{5}{*}{ III. } & \multirow{5}{*}{ Secondary civilizations } & Babylon, whose roots are Sumerian \\
\hline & & An Indian whose root is Harappa \\
\hline & & Syria, rooted in Mina \\
\hline & & Ellin, whose root is Minoy \\
\hline & & Chinese with shan roots \\
\hline \multirow{5}{*}{ IV. } & \multirow{5}{*}{ Higher religions } & Judaism and Zoroastrianism, rooted in Babylon \\
\hline & & Hinduism with Indian roots \\
\hline & & Islam, rooted in Syria \\
\hline & & Christianity with Hellenic roots \\
\hline & & Buddhism, which has its roots in India \\
\hline \multirow{4}{*}{ V. } & \multirow{4}{*}{ Tertiary civilizations } & $\begin{array}{l}\text { The root is Ancient Hindu, Hindu formed under the } \\
\text { influence of Buddhism }\end{array}$ \\
\hline & & $\begin{array}{l}\text { Iran, which is rooted in Syria and formed under the } \\
\text { influence of Islam }\end{array}$ \\
\hline & & $\begin{array}{l}\text { An Arab with its roots in Syria, formed under the influence } \\
\text { of Islam }\end{array}$ \\
\hline & & $\begin{array}{l}\text { Western Europe, formed under the influence of } \\
\text { Christianity, whose roots are Hellenic }\end{array}$ \\
\hline
\end{tabular}

${ }^{1}$ Arnold Joseph Toynbee is a member of the British Academy of Sciences, a professor at the Universities of Oxford, London, Birmingham, Princeton, and director of the Koroleva Institute of International Affairs. Author of the ten-volume Historical Studies, A Study of History. 


\begin{tabular}{|l|l|l|}
\hline \multirow{n}{*}{} & $\begin{array}{l}\text { Eastern Europe, formed under the influence of Christianity, } \\
\text { whose roots are Hellenic }\end{array}$ \\
\cline { 2 - 2 } & $\begin{array}{l}\text { The Far East, which is rooted in China and formed under the } \\
\text { influence of Buddhism }\end{array}$ \\
\hline
\end{tabular}

As a very strong sociologist, A. Toynbee, in his monograph published in 1967, expressed the view that the socialist system was in crisis [19:26 p].

If you look at A. Toynbee's civilization periodicity, he does not consider the five hearths of the Ancient East mentioned in the first stage of civilization to be complete, ending with the phrase "and others." In the phrase "and others," he meant, of course, new civilizations being discovered by archaeologists.

We are far from believing that this conclusion of A. Toynbee is the most correct, that this periodization should be accepted. We have shown it only as one of the acceptable steps in this direction in the chronology of history.

It should be noted that some work has been done in the history of Uzbekistan on the issue of a civilized approach to the periodization of history. The work done was carried out over a period or historical period taken. Since the 1930s, the Khorezm Archaeological Expedition led by S.P. Tolstov has raised the idea of "Ancient Khorezm Civilization". The rich material culture created by the ancient Khorezm people and its place in the history of the peoples of Central Asia [20: 341 p .; 21: 149$168 \mathrm{p}]$.

In the post-World War II years, given the role of Central Asian thinkers in the cultural and scientific life of the peoples of the world during the Middle Ages, the idea of a "Muslim renaissance" emerged in world history [22; 23]. Muhammad Khorezmi, Akhmad Fergani, Abu Nasr Farabi, Abu Ali ibn Sino, Abu Raykhan Beruni, Abu Abdullah Rudaki, Yusuf Khas Hajib, Makhmud Kashgari, Akhmad Yugnaki, Imam alBukhari, Abu Isa Mukhammad Termezi, Makhmud az-Zamakhshari, and Akhmad Yassavi The historical contributions of dozens of scholars to the development of mankind have been recognized by the people and scientists of the world.

Due to independence, the attitude to the history of Amir Temur and the Timurids changed. The term "civilization of the Timurids period" or "Samarkand civilization" began to be applied to the technical progress and material culture created during their time, to the history of public administration, especially to innovations in architecture.

A number of scientific studies have been done on ancient history, early civilizations. Academician A.A. Askarov, in his scientific research published in 2007 and 2015, believes that the history of humanity has experienced 5 times the greatest civilization in its development [2: 18-19 p .; 24: 69-90 p]. He also notes that the Bronze Age cultures of ancient Bactria and Margiana in the 2nd millennium BC were recognized by some archaeologists and historians as the fifth hearth of primitive 
civilization under the name of the Oxus civilization [24: 69-90 p].

Noting the services of T. Sh. Shirinov on the formation of the first cities, it is necessary to recognize the services of A.S.Sagdullaev on the emergence and development of the first civilizations and states in the southern regions of Central Asia [25: 42 p; 26: 40p; 27]. A.S. Sagdullaev studied the development of the first states in terms of periods and types [26: 40-41 p; 28: 22-31 p].

In this regard, published in 2001, Ancient Civilization of Uzbekistan": In the book "Excerpts from the history of statehood and law" academician E.V. Rtveladze was divided into the following types, depending on the method of governing the ancient states on the territory of Uzbekistan:

1. Monarchy, the method of governing absolute monarchy;

2. Confederate monarchy, mode of government - a limited monarchy;

3. Land tenure is a kingdom passed down from generation to generation [29: 54-57 p].

It is in this book that the stages of the emergence and development of ancient states on the territory of Uzbekistan are divided into six stages [29: 48-50 p]. A.S. Sagdullaev and E.V. Rtveladze begin the history of statehood in the territory of Uzbekistan in the Late Bronze Age. He believes that the first buds of statehood appeared in the second half of the second millennium B.C.

Other researchers, including A.A. Askarov and T.Sh. Shirinov, who conducted research on the Bronze and Early Iron Ages, concluded that the first statehood in Jarqotan had the appearance of city-states of the type "Chiefdom" (Чифдом), "Dwarf state" (Карликовое государства), “Name” [30: 85 p].

The research of I.M. Dyakonov and V.A. Yakobson on the typology of the first states of the ancient East is noteworthy. They showed the following three stages in the emergence and development of the first states:

1. The oldest form of states is "city-states" or "name";

2. Territorial kingdoms (territorial states);

3. Large states are empires [31: 3-12 p].

Due to the lack of theoretical historians among specialists in the history of Uzbekistan, we see a lack of consensus on the emergence of the first states. In this regard, we need to improve the typology of the first states created for the history of the Ancient East, firstly, the territory we occupy is an integral part of the Ancient East, and secondly, this typology as a general rule of development for many regions of the world, including Mesoamerica [32; 33: 81-85 p], also accepted for the ancient Russian statehood [34].

The oldest type of statehood, city-states, is relatively well studied in Sumer [31: 3-12 p]. The territory of Sumer was found to be ruled by 13 independent city-states [33: 76-77 p].

Researchers cite the Hittite, Mitanni, and Middle Assyrian kingdoms in the Ancient East as examples of the second-territorial state stage of development of the first states [31: $p$. 5-6; 33:83p]. These kingdoms were like a military alliance of "city-states". At the same time, weak city-states were forced to pay tribute taxes and provide military assistance to a stronger central state while maintaining their internal autonomy. 
The third stage in the development of statehood was the period of "empires", which, according to I.M. Dyakonov and V.A. Yakobson, It is the period of the Assyrian Empire in the IXVII centuries. "Empires" are characterized by vast territories that are economically, geographically, culturally, and ethnically diverse, forcibly annexed to the state. These areas are managed from a single center. In contrast to the period of territorial kingdoms, administrative divisions (region, province, satrap) were also typical for "empires". For an "Empire" to exist, it is important to have a standing army that is perfectly armed and welltrained [31: 3-12 p ; 27].

In recent years, as a result of archaeological work in Central Asia, especially in Uzbekistan, new information has been obtained about the emergence and stages of development of the first states [35: 7-13 p ; 36: 67-72 p]. It was possible to compare this information with the material sources of the first states of the Ancient East. The monuments of Altyndepa, Namazga-Tepa, Ulugdepe, Gonur Tepe, Togolok (Southern Turkmenistan), Dashli (Northern Afghanistan), and Djarkutan (Southern Uzbekistan) in Central Asia, with all their archeological features, corresponding to the first stage of development of the first states - the "city-state". observed [27]. It can be seen that they acted as a center of "citystates" formed on the scale of a small oasis, or resembled the "city-states" of the Ancient East. It is necessary to compare these monuments with the city-states of the Ancient East, and on this basis to determine the type of these monuments, the chronological periods of these "city-states", which are the first stage of statehood.
The second stage of statehood in the ancient East, the monarchy (territorial state), also has the opportunity to be observed archeologically. Depending on the type of archeological monuments and their location based on irrigation facilities, it became possible to divide them into regions, agricultural oases.

As a result of research, there were three agricultural oases in the Surkhandarya region during the Early Iron Age, the centers of which (Kyzyl-Tepa, Djandavlat-Tepe, Khaitabod-Tepe) were archeologically identified [37: 18-21 p]. A similar situation is observed in Sugd (Sangirtepa, Uzunqir, Erkurgan, Kuktepa, Afrosiyab), Fergana (Dalvarzin-Tepe, Chust, Ashkal-Tepe) [38:42 p; 39; 40; 41: 23-40 p]. The configuration of these agricultural lands into territorial states, and their confederation, revealed that the kingdoms of Ancient Bactria, Ancient Kharezm, Ancient Sugd, or Ancient Fergana ruled, and they were not the oldest states in Central Asia, but the second-territorial states in the history of Uzbek statehood. proved [27].

As mentioned above, the third stage of the typology of the first states in the Ancient East the empire stage - is associated with the Assyrian Empire, while in Central Asia this stage is associated with the millennium BC. It is characterized by VI-IV centuries, that is, these areas were also included in the Achaemenid Empire.

The following words of the First President have become our way of working in the periodization of the history of Uzbekistan, in the formation of civilized views: "Any civilization is the product of the activities and interaction of many peoples, nations, and peoples ..." [42: 146]. 
The American Journal of Social Science and Education Innovations (ISSN - 2689-100x)

Published: April 28, 2021 | Pages: 158-171

During the period of independence, many works have been done to periodization the history of Uzbekistan and the history of Uzbek statehood. We will attach some of them in tabular form.

Periodization of the history of Uzbekistan

\begin{tabular}{|c|c|c|c|c|c|c|c|c|}
\hline & Naming of periods & 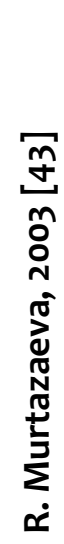 & 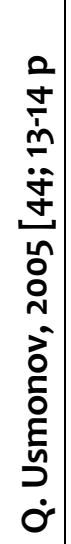 & 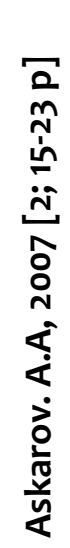 & 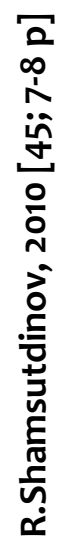 & 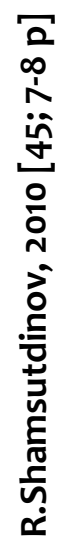 & 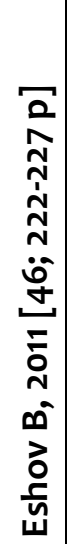 & 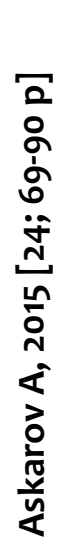 \\
\hline \multirow{6}{*}{ I } & Primitive community system & & + & & & & & \\
\hline & Early community period & & & & & + & & \\
\hline & The oldest period in the history of Uzbekistan & & & & & & + & \\
\hline & The oldest period & + & & & & & & \\
\hline & The period of the primitive gang & & & + & + & & & + \\
\hline & $\begin{array}{l}\text { The period of formation of the primitive tribe community and } \\
\text { property ownership }\end{array}$ & & & + & + & & & + \\
\hline \multirow{3}{*}{ II } & $\begin{array}{l}\text { The period of transition to the first statehood and the } \\
\text { development of statehood }\end{array}$ & & & & & & + & \\
\hline & $\begin{array}{l}\text { The oldest and most ancient state structures in the territory of } \\
\text { Uzbekistan }\end{array}$ & & & & & + & & \\
\hline & Ancient period: the formation and development of statehood & & + & & & & & \\
\hline \multirow{5}{*}{ III } & Early medieval period & & & + & + & & & + \\
\hline & The Middle Ages & + & + & + & & + & & + \\
\hline & The medieval period in the history of Uzbekistan & & & & & & + & \\
\hline & Developed medieval period & & & & + & & & \\
\hline & The period of Uzbek khanates & & & & + & & & \\
\hline \multirow{4}{*}{ IV } & The period of tsarist colonization & + & + & & & & & \\
\hline & The period of colonialism of the Russian Empire & & & & + & & & \\
\hline & $\begin{array}{l}\text { Turkestan during the invasion and colonialism of the Russian } \\
\text { Empire }\end{array}$ & & & & & + & & \\
\hline & The period of colonialism and national awakening & & & + & & & & + \\
\hline & The period of tsarist colonization and Soviet rule in Uzbekistan & & & & & & + & \\
\hline & Uzbekistan during the Soviet era & + & & & & + & & \\
\hline & The period of dictatorial Soviet rule & & + & & & & & \\
\hline
\end{tabular}


The American Journal of Social Science and Education Innovations

(ISSN - 2689-100x)

Published: April 28, 2021 | Pages: 158-171

Doi : https://doi.org/10.37547/tajssei/Volume03Issue04-24

2021: 5.857

OCLC - 1121105668

\begin{tabular}{|c|c|c|c|c|c|c|c|}
\hline \multirow{3}{*}{$\mathrm{V}$} & The period of Soviet rule & & & & & & + \\
\hline & "Soviet-era" in the history of Uzbekistan & & & + & & & \\
\hline & Soviet-era & & + & & & & \\
\hline \multirow{5}{*}{$\mathrm{VI}$} & The period of national independence. & + & & & & & \\
\hline & $\begin{array}{l}\text { The period of national independence, building a democratic } \\
\text { state, and civil society }\end{array}$ & & + & & & & + \\
\hline & $\begin{array}{l}\text { The period of building Uzbekistan's national independence, } \\
\text { democratic state, and civil society }\end{array}$ & & & + & & & \\
\hline & $\begin{array}{l}\text { The period of independence and national independence of } \\
\text { Uzbekistan }\end{array}$ & & & & & + & \\
\hline & Uzbekistan's path to independence and development & & & & + & & \\
\hline \multicolumn{8}{|c|}{ Periodization of the history of Uzbek statehood } \\
\hline & \multicolumn{4}{|l|}{ Naming of periods } & 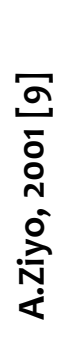 & & 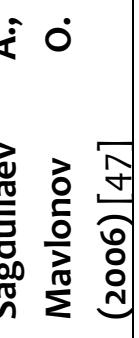 \\
\hline \multirow[t]{2}{*}{ I } & \multicolumn{4}{|l|}{ History of the first states } & & \multicolumn{2}{|c|}{+} \\
\hline & \multicolumn{4}{|c|}{ Founding of the first statehood and the history of Uzbek statehood in BC } & + & & \\
\hline \multirow[t]{3}{*}{ II } & \multicolumn{4}{|c|}{ Uzbek statehood in the period from the beginning of AD to Islam } & + & & \\
\hline & \multicolumn{4}{|l|}{ Uzbek statehood in the X-XIII centuries } & + & & \\
\hline & \multicolumn{4}{|l|}{ Statehood and governance in the advanced Middle Ages } & & + & \\
\hline \multirow[t]{2}{*}{ III } & \multicolumn{4}{|l|}{ Uzbek statehood during the reign of Amir Temur and the Timurids } & + & & \\
\hline & \multicolumn{4}{|c|}{$\begin{array}{l}\text { The development of statehood in Transoxania and Khorasan during the reign of Amir } \\
\text { Temur and the Timurids }\end{array}$} & & + & \\
\hline \multirow[t]{2}{*}{ IV } & \multicolumn{4}{|c|}{ Uzbek statehood in the XVI-XIX centuries } & + & & \\
\hline & \multicolumn{4}{|c|}{$\begin{array}{l}\text { Uzbek khanates in the late Middle Ages: administrative structure and public } \\
\text { administration }\end{array}$} & & + & \\
\hline
\end{tabular}

Then academician E.V. Rtveladze periodized the history of the statehood of Uzbekistan [29; 48].

We are far from thinking that these cycles are the most perfect. Unacceptable periodizations also have the right to stand in science as an idea, of course. However, it should be noted that the formation of a group of theoretical historians on the periodization of the history of Uzbekistan and the solution of this problem is one of the most pressing issues in the science of history today.

We have mentioned above the services of T.Sh.Shirinov in the study of the history of the first urban culture and civilizations in Central Asia. He critically discusses the concepts developed in the science of history on this subject, and points out the following characteristics of the first cities: 
1. The presence of palaces inhabited by community leaders or rulers;

2. The presence of majestic temples that are the religious center of the country;

3. Presence of an arch surrounded by defensive walls and location of houses inhabited by palace inhabitants in the territory of the arch;

4. Availability of residential buildings in a large area, the location of public facilities, the concentration of productive forces and handicraft workshops in the area;

5. Availability of highly developed handicraft quarters (ceramics, pottery, textiles, construction, stone and leather tanning);

6. The presence of "rich" tombs where seals or valuables are found;

7. Radical differences between the houses inhabited by the population, indicating the hierarchy of urban population;

8. Finding items that are specific to other cultures, indicating the development of trade;

9. Presence of glyptics, epigraphy, and primitive writing forms [30: p. 2].

We would like to share our views on the development of cities in Central Asia, using T.Sh. Shirinov's scientific research on the archaeological features of the first cities.

It is known that cities arise during the period of first-class society, that is, simultaneously with states [31: p. 3-16]. The relationship between cities and states has not been sufficiently studied in the archeology of Central Asia. For this reason, there is no consensus among scholars on the emergence and development of cities and states.

While some researchers have described the first urban monuments of the Late Bronze Age as "urbanized villages of the Bronze Age" [49: 68-71 b], others call them shaharmonand (protocity) [50: p. 131]. The same situation is observed in the description of the cities of the Early Iron Age. While E.V. Rtveladze classifies the cities of this period as "emerging cities", B.A. Litvinsky describes them as "urbanizing villages" [49: p. 69; 50: p. 131].

The main reason for the scientific discussion of scientists about the emergence and development of cities is that the issue of the emergence and development of cities and states is studied as a separate scientific problem. This is historically and methodologically incorrect, as the first cities emerged as the centers of the first states, and their development is also interdependent. From this point of view, the emergence of cities and states should be considered as a problem, and we consider it expedient to divide their development into the following periods:

1. Cities (city-states) formed within agricultural lands. The cities of this period Founded in the II millennium. Jarkoton, Dashtli I monuments studied in the territory of ancient Bactria, are city-states, in the example of which the formation of the city and the state as an organism is observed.

2. Cities that acted as regional state centers. The cities of this period are mainly B.C. I was formed at the beginning of the millennium. Kyzyl-Tepa, Jondavlattepa, Khaitobodtepa (Bactria), Dalvarzin, Chust, Ashkoltepa (Fergana), Koktepa, Podayotoqtepa (Sogd), and other monuments were the political and ideological centers of the regional states. It is typical for this period to have only one city within a single territorial state. 
3. Centralized states, cities of the empire period. This stage of urban development began in Central Asia with the emergence of the ancient kingdoms of Bactria and Greater Khorezm and their incorporation into the Achaemenid Empire.

The territory of centralized states is very large, it covers one or several states. By this time, cities began to fall into categories. Cities as the capitals of a centralized state or empire (Suza, Persopol), satrapic centers in the territory of a centralized state (Bactria). Cities in the territory of satrapies can be divided into large or small cities depending on their political position and economic opportunities (such as Afrosiyob, Kyzyl-Tepa, Khaitobodtepa, Koktepa).

In his work, T.Sh.Shirinov visited the palace of the leaders or rulers of the community at the Jarqoton monument, the religious center, the arch surrounded by defensive walls, the many buildings where the city dwellers lived and worked, the highly developed handicrafts, gave a broad description of the "rich" tombs where seals or valuables were found, objects of other cultures that attest to the development of trade, and acknowledged the existence of glyptics, epigraphy, and primitive forms of writing [30:20 p], Elsewhere in this work, “... considers the existence of writing as a secondary feature of the first cities in communities that are completely subject to tradition", where oral creativity is developed, and where public administration is less developed [30: $27 \mathrm{p}$ ].

Many urbanist scholars consider writing to be the main symbol of the first civilization. It is impossible even to imagine civilization without writing. The inscription was also formed in five centers of the above-mentioned ancient Eastern civilization. However, regarding the first writing system in Central Asia, the period before the introduction of the Aramaic writing system is not defined. Professor Sh.B. Shaidullaev published sources about the pictographic symbol of the Copolly culture - the pictographic inscription "Goose" of the early Iron Age and expressed the opinion that these symbols were the first way of writing $[51 ; 52]$. Thoughts on pictographic inscriptions of pottery culture are the first stage works on the history of the writing of the peoples of Central Asia. They identified the characters drawn on the pottery of the Sopolli culture, indicating that they were pictographic symbols. In our opinion, the main work should now be done. We hope that the study of each symbol in terms of form, the definition of the method of drawing, the classification of symbols into types by shapes, the comparison with the pictographic inscriptions of the Ancient East, the definition of the meaning of symbols will yield results.

These are the views of scientists on the views of civilization on the history of Uzbekistan, on the amount of work done. The Uzbek people are one of the nations that have made a great contribution to the development of world culture. Therefore, no one has the right to forgetting that it is the primary task of Uzbek historians to present these services of our people in chronological order, on the basis of civilizational views, and that this work is a great responsibility of Uzbek historians.

\section{CONCLUSION}

It is a requirement of the time not only to form civilizational views in the periodization of the history of Uzbekistan but also to develop it on a methodological basis. During the Bronze Age, 
the first city-states were established in the territory of Southern Uzbekistan, the first civilization was formed. It should be noted that we have not been able to adequately study and evaluate the rich material culture created by our ancestors, the civilizations they created. The ancestors of the Uzbek people have built great empires, made a great contribution to the development of the culture of the peoples of the world, created civilizations. These bright pages will become even clearer only if we take a civilized approach to the periodization of the history of Uzbekistan.

\section{REFERENCES}

1. Бартольд В.В. История культурной жизни Туркистана. - Л., 1927. - С.3.

2. Асқаров А.А. Ўзбек халқининг этногенези ва этник тарихи. - Тошкент, 2007. - 15-24 бетлар.

3. Струве В.В. Проблемы зарождения, развития и упадка рабовладельческих обществ древнего Востока // «Известия ГАИМК». Вып. 77. - М.- Л. 1934. - С. 23-34.

4. Толстов С.П. Основные вопросы древнейшей истории Средней Азии // ВДИ, № 1. - М., 1938. - С. 3-21.

5. Материалы пленума // КСИИМКА, XXVIII. 1948. - С. 8-28.

6. Материалы объединённой сессии, посвященной истории Средней Азии и Казахстана в до октябрьский период. Ташкент, 1955.

7. История Узбекской ССР. Том 1. - Ташкент, 1967, - С.15.

8. Васильев А.С. История Востока. Том 1. M., 2003. - $512 \mathrm{C}$.

9. Азамат Зиё. Ўзбек давлатчилиги тарихи: (Энг қадимги даврлардан Россия босқинига қадар) // Маъсул мухаррир: Б. Ахмедов /. -Т.: «Sharq», 2001.
10. Renfrew $C$. The emergence of civilization: The Cuclades and the Aegean in the third millennium B.C. - London, 1972, - P. 213.

11. Чайлд Г. У истоков европейской цивилизации. ИИл, М., 1952.

12. Чайлд Г. Древнейший Восток в свете новых роскопок. ИИЛ, М., 1956.

13. Childe V.G. The urban revolution // Towh planning Review. Vol. 21. 1950, - P. 9 -16.

14. Adams R.Mc. History patterns of Mesopotamian irrigation agriculture // Irrigation's impact on Society. - Tucson, 1974. - P. 345-357.

15. Servis E.R. Privitive social organisation. An evolutionary perspective. - Nev Vork, 1971. P. 68-73.

16. Flannery K.V. The cultural of civilization ॥ Annual Rewiew of ekology Sistematies, 1972. №3. - P. 21-34.

17. Тойнби А.Ж. Постижение истории. - М.: 1991.

18. Сорокин П.А. Человек. Цивилизация. Общество. - М.: 1992.

19. Toynbee A. The impact of the Russian Revolution 1917-1967. -London, 1967 - p. 26.

20. Толстов С.П. Древний Хорезм. - М.: 1948. C. 341.

21. Толстов С.П. Работы Хорезмской археолого-этнографической экспедиции АН СССР в 1949-1953 гг. // Труды ХАЭЭ. Т.2, M.: 1958. - C. 149-168.

22. Мец А. Мусульманский ренессанс / Перевод с немецкого А. Е. Бертельса. М.: Наука, 1966.

23. Смирнов Н.В. Мусульманский ренессанс. - М., 1967.

24. Ўзбек халқининг келиб чиқиш тарихи. / А. Асқаров. - Тошкент: «O`zbekis- ton» NMIU, 2015.

25. Ширинов Т.Ш. Ранняя городская культура эпохи бронзы юга Средней Азии. 
Автореф. дисс. ... докт. ист. наук. - М.: ИА АН России. 1993. - С.42.

26. Сагдуллаев А.С. Оседлые области на юге Средней Азии в эпоху раннего железа (генезис культуры и социально экономическая динамика). Автореф. дис. ... док. ист. наук. - М.: МГУ.1989. - С. 40.

27. Шайдуллаев Ш.Б. Этапы возникновения и развития государственности на территории Узбекистана. Автореф. дисс. ... док. ист. наук. - Самарканд, ИА АН РУз. 2009.

28. Сагдуллаев А.С, Аминов Б, Мавлонов ў, Норқулов Н, Ўзбекистон тарихи: давлат ва жамият тараққиёти. І-қисм. - Тошкент, Академия, 2000. Б. 22-31.

29. Ртвеладзе Э.В, Саидов А,X, Абдуллеев Е.В. Қадимги Ўзбекистон цивилизацияси: давлатчилик ва хуқуқ тарихидан лавхалар. - Тошкент, Адолат, - 2001. - Б. 54-57.

30. А.А. Аскаров, Т.Ш.Ширинов. Ранняя городская культура эпохи бронзы юга Средней Азии - Самарканд, 1993. - С.85.

31. Дьяконов И. М, Якобсон В. А. «Номовые государства», «территориальные царства», «полисы» и «империи». Проблемы типологии // ВДИ. - М.: - № 2, 1982. - С. 3-12.

32. Гуляев В.И. Города государства Мая. (Структура и функции города в раннеклассовом обществе). - М.: 1979. 219 c.

33. Гуляев В.И. Типология древних государств: Месопатамия и Мезоамерика // Древние цивилизации Востока. Материалы II Советско- Американского симпозиума. - Ташкент, 1986. - С. 81-85.

34. Илюшечкин В.П. Теория стадийного развития общества. - М.: 1996. - 296 с.

35. Ширинов Т.Ш. Қадимги Бақтрия подшолиги “Катта Хоразм” // Ўзбекистон давлатчилиги тарихи очерклари. Тошкент, Шарқ, 2001. - Б. 7-13.

36. Шайдуллаев Ш.Б., Икромов Н.М. Қадимги Бақтрия подшохликми кавийликми // O'zbekicton tarixi. ЎзР ФА Тарих институти журнали. 2010. № 3. 67-72 бет.

37. Шайдуллаев Ш.Б. Северная Бактрия в эпоху раннежелезного века. - Ташкент, 2000. - C. 18-21.

38. Исамиддинов М.Х. Генезис городской культуры Самаркандского Согда (проблемы взаимодействия культурных традиций в эпоху раннежелезного века и в период античности). - Т.: 2002. - С.42.

39. Сулейманов Р.Х. Древний Нахшаб. Ташкент-Самарканд, 2000.

40. Заднепровский Ю.А. Раннежелезный век Ферганы и проблемы возникновения Даваньского государства // Раннежелезный век Средней Азии и Индии. Тезисы докладов СоветскоИндийского симпозиума. - Ашгабад, 1984.

41. Матбобоев Б.Х. Ўзбек давлатчилигининг илк босқичларида Фарғона. // Ўзбек давлатчилиги тарихида қадимги Фарғона. Маъруза матнлари. - Наманган, 2001. - Б. 23-40.

42. Каримов И.А. Тарихий хотирасиз келажак йўқ // Биз келажагимизни ўз қўлимиз билан қурамиз. - Тошкент, 1999. - Б. 134.

43. Ўзбекистон тарихи: (Олий ўқув юртларининг номутахассис талабалари учун дарслик). Т., “О‘АJBNT» Маркази, 2003.

44. Usmonov Q., Sodiqov M, Burxonova S. O‘zbekiston tarixi. Darslik. - T.: Moliya, 2005.

45. Shamsutdinov R., Karimov Sh. Vatan tarixi. K. 1/ Mas'ul muharrir: A. Sagdullayev; Taqrizchilar H.Sodiqov va boshq. - T.: «Sharq», 2010. 
46. Эшов Б. Ж. Ўзбекистон тарихини даврлаштириш масалалари/ Ўзбекистон тарихини ўқитиш муаммолари: тажриба ва истиқболлари илмий-услубий анжумани материаллари.-Тошкент, 2011. 222-227 бетлар.

47. Сагдуллаев А, Мавлонов Ў. Ўзбекистонда давлат бошқаруви тарихи (қадимги даврлардан XIX асрнинг ўрталарига қадар). - Т., “Akademiya”, 2006.

48. Ртвеладзе Э.В, Саидов А.Х, Абдуллаев Е.В. Очерки по истории цивилизации древнего Узбекистана: государственность и право. Ташкент, 2000. - 234 с.; Ртвеладзе Э.В, Саидов А. Х, Абдуллаев Е.В. Қадимги Ўзбекистон цивилизацияси: давлатчилик ва хуқуқ тарихидан лавхалар. - Тошкент, Адолат, - 2001. - 2396.

49. Ртвеладзе Э.В. Формирование городов Бактрии-Тохаристана // Городская среда и культура Бактрии - Тохаристана и Согда (IV в. до н.э. - VII в. н.э.). Тезисы докладов Советско - Французского коллоквиума. Ташкент, 1986. С. 68-71.

50. Литвинский Б.А. Аревний среднеазиатский город. (Местные традиции и иноземные модели) // Древний Восток. Города и торговля (III-I тыс. до н.э.). - Ереван, 1973. С.131.

51. Шайдуллаев Ш.Б. Ўзбекистон худудида давлатчиликнинг пайдо бўлиши ва ривожланиш босқичлари. Т.ф.А. дисс.автореферати. ЎзР ФА Археология институти. - Самарқанд, 2009. - 476.

52. Чариев 3.У, Шайдуллаев Ш, Аннаев Т. Ўзбекистон худудида ёзувнинг пайдо бўлиши ва тараққиёти. Т., 2005.

53.BAKIEV, A. (2007). Comparative Analysis of Timurids Genealogy in Historiography. Ölümünün 600. yılında emir Timur ve mirası: uluslararası sempozyumu, 165 .
54.Bakiev, A., \& Yuldasheva, Z. (2020). THE FIFTH CIVILIZATION OF THE ANCIENT EAST. Theoretical \& Applied Science, (8), 39-45. 55.BAKIEV, A. (2020). The Social Character of Oxus Civilization.

56.Zubayda, Y., \& Anvar, B. (2020). Sistemic analysing of written sources. ACADEMICIA: An International Multidisciplinary Research Journal, 10(5), 357-371. 